\title{
Microbiology of retroperitoneal abscesses in children
}

\author{
ITZHAK BROOK \\ Department of Pediatrics, Georgetown University, Washington, DC, USA
}

\begin{abstract}
Samples of pus from 41 children with retroperitoneal abscess treated between 1974 and 1994 yielded a total of 125 organisms (3.0 isolates/specimen); 58 isolates were aerobic and facultative species (1.4/specimen) and 67 were anaerobic (1.6/specimen). Aerobic bacteria only were isolated from $7(17 \%)$ abscesses, anaerobic bacteria only from 3 (7\%) and mixed aerobic and anaerobic bacteria from 31 (76\%); $34(83 \%)$ infections were polymicrobial. The predominant aerobic and facultative isolates were Escherichia coli (19 isolates) and Staphylococcus aureus (6), and the predominant anaerobes were Peptostreptococcus spp. (18 isolates), Bacteroides spp. (22) and Prevotella spp. (5).
\end{abstract}

\section{Introduction}

Retroperitoneal abscesses are often insidious and difficult to diagnose and cause high morbidity and mortality. They comprise infections of four anatomical spaces - anterior retroperitoneal, posterior retroperitoneal, retrofascial and pelvic retroperitoneal [1-4]. Previous studies of the microbiology of retroperitoneal abscesses in adults and children have been limited to infection of only one space [5-10], or did not define the microbiology according to the anatomical space $[2,5,11]$ or did not use methods adequate for the recovery of anaerobic organisms $[1-4,10,11]$. Anaerobic bacteria were rarely reported from paediatric cases of retroperitoneal abscesses [10]. This retrospective report summarises the microbiology of retroperitoneal abscesses in 41 children treated over a period of 20 years.

\section{Patients and methods}

\section{Patients}

The 41 children were treated in the University of California Medical Center (Los Angeles, CA, USA), County Medical Center (Los Angeles, CA), Fairview State Hospital (Costa Mesa, CA), Children's Hospital National Medical Center (Washington, DC) and the

Received 6 Aug. 1998; revised version received 20 Nov. 1998; accepted 13 Dec. 1998.

Corresponding author: Dr I. Brook, PO Box 70412, Chevy Chase, MD 20814-0412, USA.
Navy Hospital (Bethesda, MD) between June 1974 and June 1994. Patients were 8 months - 18 years old (average 11.3 years) and 25 were male. Antimicrobial therapy was given to 27 patients before collection of samples.

The abscesses comprised 21 anterior retroperitoneal abscesses (one oesophageal, one duodenal, four pancreatic, 11 from the lower gastrointestinal tract and four of unknown origin), six posterior retroperitoneal (perinephric), seven retrofascial (six psoas and one iliac muscle) and seven pelvic retroperitoneal abscess. The data on the six perinephric abscesses were presented previously [7].

\section{Microbiological examination}

Specimens were obtained through open surgical procedures, either by aspiration of the pus into a syringe that was sealed with a rubber stopper after evacuation of the air or by a swab that was transported in an anaerobic transport tube (Port-A-Cul ${ }^{\circledR}$, Becton Dickinson Company). The time between collection and culture of specimens was $30 \mathrm{~min}-2 \mathrm{~h}$.

Specimens were cultured on sheep blood 5\% agar, chocolate agar (both incubated in air with $\mathrm{CO}_{2} 5 \%$ ) and MacConkey agar (incubated aerobically) at $37^{\circ} \mathrm{C}$ and examined at 24 and $48 \mathrm{~h}$. For anaerobes, samples were cultured on pre-reduced brucella blood agar with vitamin $\mathrm{K}_{1}$, blood agar containing kanamycin and vancomycin, blood agar containing phenylethyl alcohol and in thioglycolate broth containing haemin and vitamin $\mathrm{K}_{1}$ [12]; all were incubated in $\mathrm{GasPak}^{\circledR}$ jars (Baltimore Biological Laboratories) at $37^{\circ} \mathrm{C}$ and 
examined after 48 and $96 \mathrm{~h}$. Anaerobes were identified by techniques described previously [12]. Aerobic bacteria were identified by conventional methods [13].

Blood for cultures was drawn from 35 patients, most often from an antecubital vein, after preparation of the area with povidone-iodine, and inoculated at the bedside into two bottles, one for aerobic bacteria and the other for anaerobic bacteria.

\section{Results}

A total of 125 isolates (3.0/specimen) was obtained from the abscesses (Table 1); 58 were aerobic and facultative species (1.4/specimen) and 67 (1.6/ specimen) were anaerobes. Aerobic bacteria only were isolated from $7(17 \%)$ abscesses, anaerobic bacteria only from $3(7 \%)$ and both aerobic and anaerobic bacteria from 31 (76\%). Polymicrobial infection was present in $34(83 \%)$ abscesses; the number of isolates ranged from two to five.

The predominant aerobic and facultative isolates were Escherichia coli (19 isolates) and Staphylococcus aureus (6), and the predominant anaerobes were Peptostreptococcus spp. (18 isolates, including five $P$. micros, three $P$. prevotii, three $P$ anaerobius, two $P$. magnus and one $P$ asaccharolyticus), Bacteroides spp. (22, including $11 \mathrm{~B}$. fragilis, five $B$. thetaiotaomicron, three $B$. vulgatus and one $B$. distasonis), Prevotella spp. (5 - $2 P r$. intermedia, two Pr. melaninogenica, one Pr. bivia) and Clostridium perfringens (five).

Sixteen isolates identical to those from the abscesses were cultured from $14(40 \%)$ of the 35 patients from whom blood cultures were collected. These were $E$. coli (six), Bacteroides spp. (four), Peptostreptococcus spp. (two), S. aureus (two), Klebsiella pneumoniae (one), Fusobacterium spp. (two) and Clostridium sp. (one).

Single isolates were obtained in seven $(17 \%)$ instances - four isolates of $S$. aureus and one each of $E$. coli, B. fragilis and Peptostreptococcus sp. The number of anaerobic isolates per site generally outnumbered the number of aerobic or facultative isolates. The number of anaerobic isolates was highest in pelvic abscesses $(2.1 /$ site). S. aureus was more commonly isolated from posterior, retrofascial and pelvic abscesses. Neisseria gonorrhoeae, Pr. bivia and group B streptococci were isolated only from pelvic abscesses. Clostridium spp. were mostly from anterior retroperitoneal sites. Bacteroides spp. and E. coli isolates predominated in abscesses related to the lower gastrointestinal tract.

Antimicrobial therapy was given and surgical drainage was performed for all patients. The antimicrobial agents used were aminoglycosides (34 cases), clin- damycin (16), methicillin (15), amoxicillin (11), cefoxitin (7), metronidazole (5), vancomycin (5), ceftazidime (4), imipenem-cilastatin (2), ticarcillinclavulanate (2) and cefazolin (1).

Predisposing or associated clinical conditions were present in most cases $(37 ; 90 \%)$. These included ruptured appendix (nine cases), trauma (eight), previous surgery (seven), remote infection (six), Crohn's disease (four; all psoas abscesses), splenectomy (four), immunodeficiency (three), osteomyelitis (three), diabetes (three), malignancy (three), steroid intake (two), rupture of a hollow viscus (two) and renal transplant (one).

\section{Discussion}

This study demonstrated the occurrence of aerobic and anaerobic bacteria in retroperitoneal abscesses in children. Organisms similar to those reported in the present study have been reported from intra-abdominal [14] and subphrenic abscesses [15]. In contrast to previous reports $[1-4,10,11]$, this study demonstrated the isolation of anaerobic bacteria from all the retroperitoneal anatomical spaces. Infections of the retroperitoneal spaces usually originate from sites where anaerobic bacteria are part of the normal flora. These include the upper and lower gastrointestinal tract and the vagina and cervix, where anaerobic bacteria are present at concentrations of $10^{9-11}$ organisms $/ \mathrm{ml}$, outnumbering aerobic and facultative species by $100-$ 1000:1 [16]. The importance of both aerobic and anaerobic components acting synergically in such infections has been demonstrated in experimental studies of animals [17-19]. The virulence factors of the most prevalent anaerobic species, $B$. fragilis, include $\beta$-lactamase production [20], elaboration of other enzymes and metabolites, and possession of a capsule [20]. Synergy may be a result of mutual protection from phagocytosis and intracellular killing [21], production of essential growth factors [22] or lowering of oxidation-reduction potentials in host tissues [23].

Management of mixed aerobic and anaerobic infections requires surgical correction and drainage of pus and the administration of antimicrobial agents effective against both aerobic and anaerobic bacteria [24]. Without adequate therapy, infection may persist and abscesses may develop. The environment of an abscess is detrimental to many antimicrobial agents and drainage is necessary when abscesses have developed.

I am grateful to the staff of the clinical microbiology laboratories and wards at the participating hospitals and to Sarah Blaisdell for secretarial assistance. The opinions and assertions contained herein are the private ones of the author and are not to be construed as official or reflecting the views of the US Navy Department or the US naval service at large. 


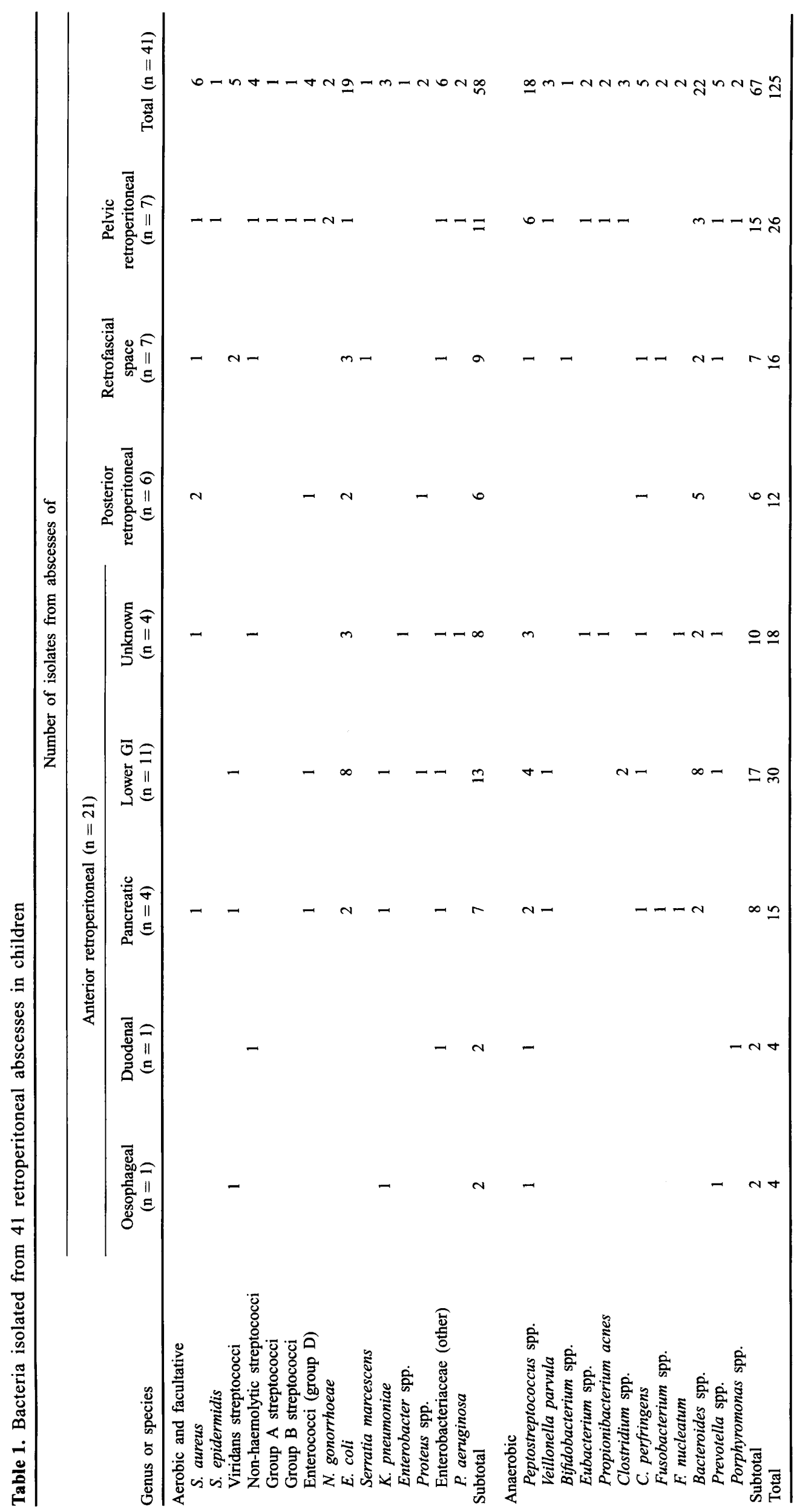




\section{References}

1. Altemeier WA, Alexander JW. Retroperitoneal abscess. Arch Surg 1961; 83: 512-524.

2. Meyers MA. Acute extraperitoneal infection. Semin Roentgenol 1973; 8: $445-464$

3. Simons GW, Sty JR, Starshak RJ. Retroperitoneal and retrofascial abscesses. A review. J Bone Joint Surg Am 1983; 65: 1041-1058.

4. Stevenson OS, Ozeran RS. Retroperitoneal space abscesses. Surg Gynecol Obstet 1969; 128: 1202-1208.

5. Leu S-Y, Leonard MB. Beart RW, Dozois RR. Psoas abscess: changing patterns of diagnosis and etiology. Dis Colon Rectum 1986; 29: 694-698.

6. Greuenwald I, Abrahamson J, Cohen O. Psoas abscess: case report and review of the literature. $J$ Urol 1992; 147: 16241626.

7. Brook I. The role of anaerobic bacteria in perinephric and renal abscesses in children. Pediatrics 1994; 93: 261-264.

8. Altemeier WA, Alexander JW. Pancreatic abscess: a study of 32 cases. Arch Surg 1963; 87: 80-89.

9. Brook I, Frazier EH. Microbiological analysis of pancreatic abscess. Clin Infect Dis 1996; 22: 384-385.

10. Bresee JS, Edwards MS. Psoas abscess in children. Pediatr Infect Dis J 1990; 9: 201-206.

11. Chen WC, Huang JK, Chen KK, Chen MT, Chang LS Retroperitoneal abscesses. Chung Hua I Hsueh Tsa Chih Taipai 1990; 46: 208-212.

12. Sutter VL, Citron DM, Finegold SM. Wadsworth bacteriology manual, 4th edn. Belmont, CA, Star Publishing. 1985.

13. Lennette EH, Balows A, Hausler WJ, Shadomy HJ. Manual of clinical microbiology, 4th edn. Washington, DC, American
Society for Microbiology. 1985.

14. Brook I. Aerobic and anaerobic microbiology of intra-abdominal abscesses in children. South Med J 1989: 82: 1479-1482.

15. Brook I. Microbiology of subphrenic abscesses in children. Pediatr Infect Dis $J$ 1992; 11: 679-680.

16. Gorbach SL. Intestinal microflora. Gastroenterology 1971; 60: 1110-1129.

17. Altemeier WA. The pathogenicity of the bacteria of appendicitis peritonitis. An experimental study. Surgery 1942; 11: 374-384.

18. Hite KE, Locke M, Hesseltine HC. Synergism in experimental infections with nonsporulating anaerobic bacteria. $J$ Infect Dis 1949; 84: 1-9.

19. Brook I, Hunter V, Walker RI. Synergistic effects of Bacteroides, Clostridium, Fusobacterium, and anaerobic cocci, and aerobic bacteria on mortality and induction of subcutaneous abscesses in mice. $J$ Infect Dis 1984; 149: 924-928.

20. Brook I, Calhoun L, Yocum P. Beta-lactamase-producing isolates of Bacteroides species from children. Antimicrob Agents Chemother 1980; 18: 164-166.

21. Tofte RW, Peterson PK, Schemling D, Bracke J, Kim Y, Quie PG. Opsonization of four Bacteroides species: role of the classical complement pathway and immunoglobulin. Infect Immun 1980; 27: 784-792.

22. Lev M, Keudell KC, Milford AF. Succinate as a growth factor for Bacteroides melaninogenicus. $J$ Bacteriol 1971; 108: $175-178$.

23. Mergenhagen SE, Thonard JD, Scherp HW. Studies on synergistic infection-I, Experimental infection with anaerobic streptococci. J Infect Dis 1958: 103: 33-44.

24. Finegold SM. Anaerobic bacteria in human disease. New York, Academic Press. 1977. 